\title{
JUDITH BUTLER LEITORA DE MERLEAU-PONTY: POR UMA CRÍTICA AO CORPO COM SER SEXUADO
}

\author{
JUDITH BUTLER, MERLEAU-PONTY READER: A \\ CRITICISM OF THE BODY AS A SEXED BEIGN
}

\author{
Diego Luiz Warmling \\ Mestre em filosofia pela UFSC
}

Javier Andres Paez

Mestre em antropologia social pela UFSC

Resumo: Entre Merleau-Ponty e Butler, avaliaremos quão produtivas são as derivações da fenomenologia às performances de gênero. De Merleau-Ponty, se o corpo é veículo das vivências pessoais, é pela sexualidade que somos coabitados por outrem. A sexualidade está pressuposta em todas as atmosferas da vida. Contudo, diz Butler, Merleau-Ponty reedita a hipótese de uma essência heteronormativa, não-corporificada e fundante do comportamento. Pautado pela diferença sexual, Merleau-Ponty olvida o quanto as construções de gêneros estão apoiadas no fato de que os corpos se enformam às situações civilizacionais. Trata-se, então, de interpelar a enformação do corpo em gêneros normativos... É preciso que ampliemos a perspectivas sobre como os corpos dramatizam os signos culturais. Só assim vislumbraremos os gêneros como atos intencionais, performáticos e não-referenciais. Tais performances dão lugar à uma ótica onde as identidades alternativas assumem um papel crítico diante das sanções masculinistas. 
Palavras-Chave: Butler, Merleau-Ponty, Corpo Sexuado, Atos Performativos, Gêneros.

Abstract: Between Merleau-Ponty and Butler, we will evaluate how productive the derivations of phenomenology are to gender performances. From Merleau-Ponty, if the body is the vehicle of personal experiences, it is through sexuality that we are cohabiting with others. Sexuality is presupposed in every atmosphere of life. However, says Butler, Merleau-Ponty reiterates the hypothesis of a heteronormative, unincorporated essence that underlies behavior. Guided by sexual difference, Merleau-Ponty ignores how gendered constructions are supported by the fact that bodies conform civilizational situations. Therefore, it is about questioning the shaping of the body in normative genders. We need to broaden perspectives on how bodies dramatize cultural signs. Only then will we see genders as intentional, performative and non-referential acts. Such performances give rise to an optics where alternative identities play a critical role in the face of masculinist sanctions.

Keywords: Butler, Merleau-Ponty, Sexed Body, Performative Acts, Genders.

\section{Merleau-Ponty e a fenomenologia do corpo sexuado}

\subsection{Percepção e intercorporeidade}

Ta tentativa de retomar contato da consciência com o mun1 do, Merleau-Ponty enfatiza a consciência perceptiva para, dela, acentuar as fontes deste nosso envolvimento tácito com as coisas e com os outros que nos circundam. No cerne da Lebenswelt fenomenológica, sua meta é pôr em foco "a função primordial pela qual fazemos existir para nós, pela qual assumimos o espaço, [...] e descrever o corpo enquanto o lugar dessa apropriação" (MERLEAU-PONTY, 2011, p. 214). Em vias de uma filosofia que legitime os componentes das vivências em primeira pessoa, o autor reclama o primado da percepção, cuja função é restituir o sentido de nossa inserção originária num mundo e num corpo vivo, desde os quais o contato com qualquer transcendência faz-se possível. E é inquerindo uma base 
sensível, anônima, pré-pessoal e misteriosa que Merleau-Ponty encontra no corpo a potência exploratória necessária às nossas vivências pessoais e intersubjetivas.

Mundana, a percepção é a estrutura pela qual nossas vivências são possíveis. Colocando-nos em relação com os outros que nos interpelam, ela não é nem objeto em-sí nem mundo para-nós; ela é um em-si-para-nós. Ela nos dispõe diante de uma autonomia apta a acentuar um horizonte de possibilidades que não escolhemos, mas que são dadas e formam o anteparo sobre o qual está fundada a subjetividade. Ora, quando reflito sobre o que percebo, reencontro em mim "um pensamento mais velho do que eu trabalhando em meus órgãos" (MERLEAU-PONTY, 2011, p. 471). Pela percepção, abro-me à presença de outrem que "percebe suas intenções em seu corpo, com o seu corpo percebe o meu, e através disso percebe em seu corpo as minhas intenções" (MERLEAU-PONTY, 2011, p. 472). Como num acabamento daquilo que vivo e faço, a presença de outrem em meus atos destitui a reflexão tética de qualquer valoração imanente. É através do outro que, em meu corpo, percebo um prolongamento de minhas intenções. Portanto, meu corpo e o corpo de outrem são "o verso e o reverso de um único fenômeno” (MERLEAU-PONTY, 2011, p. 474).

Tudo o que sou, o sou em função de minhas relações. O que sou não depende totalmente de mim: "meu temperamento só existe [...] pelos olhos de outrem" (MERLEAU-PONTY, 2011, pp. 582-583). Sendo assim, é enquanto unidade de sentido de nossas vivências mundanas e intersubjetivas que a consciência perceptiva surge como uma inerência racional e vital da existência. Com efeito, é integrando-a ao movimento geral do ser-no-mundo que Merleau-Ponty encontra no corpo a certificação de um agente perceptivo, mundano e pré-predicativo transbordante às determinações do meio e da consciência. Nem puro objeto, nem pura ideia, o corpo esboça uma reflexão tácita que, anônima, é testemunha viva da experiência dinâmica do repertório de possibilidades provenientes da relação sujeito-mundo.

Em Merleau-Ponty, nossas vivências estão apoiadas numa dimensão ambígua e pré-pessoal que torna a reflexão um cons- 
tructo tardio. Fenomênica, intencional e perceptiva, a ação do corpo é, então, autoconsciente. Ela esboça uma espécie de reflexão tácita, tal como num sistema de interdependências. Estamos falando do "meio universal, correlato a todos os fenômenos possíveis" (FERRAZ, 2006, p. 83). Por conseguinte, enquanto fator originário da existência, a corporeidade revela-nos um modo de ser ambíguo que - implícito, confuso e misterioso - aponta à gênese de nossas experiências enquanto nos une ao mundo e aos outros num constante movimento de transcendência.

Isto posto, entendemos que, em Merleau-Ponty, a principal característica da consciência perceptiva é sua encarnação. A percepção está reportada ao corpo! Mundano, o corpo "não é coisa nem ideia, mas espacialidade e motricidade, recinto ou residência e potência exploratória" (CHAUI, 2002, p. 68). Ele "não é da ordem do 'eu penso', mas do 'eu posso"' (CHAUI, 2002, p. 68). Perceptivo, ele é investido de uma valoração existencial cujas significâncias são, em-si e para-si, vivenciadas em primeira pessoa. Na contramão dos axiomas fomentados pela imanência de um cogito atemporal, pela encarnação, compreendemos que nossas experiências são frutos da reciprocidade entre o engajamento individual e as situações mundanas. Aquém de quaisquer mecanicismos "partes extra partes", a relação dialógica entre corpo-próprio e mundo compõe, então, uma unidade viva e situacional que, em vias de um "retorno às coisas mesmas", aponta à impossibilidade de separarmos o psíquico do somático.

Para Merleau-Ponty, o organismo e as ocasiões psicológicas são entrelaçáveis, visto que não há ação subjetiva independente dos movimentos do corpo. Se todo "processo orgânico desemboca em um comportamento humano" (MERLEAU-PONTY, 2011, pp. 130-131), então não há um só ato psíquico que não tenha encontrado seu esboço em disposições fisiológicas. Assim, se é preciso ter em vista a constante atividade do corpo em situação com o meio, é através da estrutura perceptiva que podemos não apenas conceber o sentido de nossas vivências, mas entender que o homem expressa o vaivém da existência, ora corporal, ora voltada aos pessoais. 
Assim entendido, o homem é um "corpo-no-mundo" que se diferencia "de todo processo em terceira pessoa, de toda modalidade da res extensa, assim como de toda cogitatio" (MERLEAU-PONTY, 2011, p. 119). Ele é o lugar da mutua adesão entre o psíquico e o somático; e é por ele que a consciência intencional atua, revelando-nos o sentido do Ser. Apoiada numa base de significâncias vitais e originárias, a ação humana pressupõe uma espécie de envolvimento tácito, irrefletido, impessoal e dialógico do homem com a presença inalienável de um campo de possibilidades sempre já aí. Acentuando certas experiências fundamentais, é no corpo como fundante do comportamento onde rastreamos não só o leque das possibilidades humanas, mas a via pela qual restituímos o contato ingênuo, situacional e prático do homem com o mundo e com os outros.

Sendo corpo no mundo, se um projeto me é possível, “é porque estou irremediavelmente ligado com o real num sentido radical" (WAELHENS, 2006, p. XII). Isto significa que ser um corpo é "juntar-se a um meio definido, confundir-se com certos projetos e empenhar-se continuamente neles" (MERLEAU-PONTY, 2011, p. 11). Para além de perspectivas intelectualistas ou voluntaristas, experienciar o meio é habitar um organismo vivo em situação com os outros. Portanto, resta dedicar esforços à estruturação de uma filosofia cuja meta é descrever a "fundação perceptiva do mundo realizada pelo corpo próprio e no corpo próprio enquanto corpo cognoscente ou princípio estruturante" (CHAUI, 2002, p. 66). Trata-se de entender que ser corpo é estar amarrado aos outros, pois o corpo é no espaço e sua espacialidade "é o desdobramento de seu ser corpo, a maneira pela qual ele se realiza como corpo" (MERLEAU-PONTY, 2011, p. 206).

Variando segundo um sistema de equivalências, ser corpo é viver uma tomada de posição indivisa que nos faz habitar todos os espaços, meios e coisas, estando situação com elas. Apreendido de modo global e imediato, meu corpo não é para mim um saco de órgãos justapostos. Sou meu corpo "em uma posse indivisa e sei a posição de cada um de meus membros por um esquema corporal em que eles estão todos envolvidos" 
(MERLEAU-PONTY, 2011, pp. 143-144). Enquanto fenômeno instransponível daquilo que sou e faço, o esquematismo corporal é uma síntese implícita que, sempre por se fazer, revela-nos modos de ser ambíguos e indetermináveis. Sensível entre sensíveis, é a personificação do pacto de codependências entre sujeito e alteridade.

Envolvido em todos os nossos posicionamentos individuais e coletivos, o corpo é a gênese que dá sentido e lugar à experiência. Ele é a estrutura estável da existência! Perceptivo, não retém a-priori nossas vivências; abre-se à elas para que possa esboçar nossas respostas e decisões diante das possibilidades mundanas. Termômetro entre sujeito e alteridade, é a nossa inserção primordial: "a ancoragem do corpo ativo em um objeto, a situação do corpo em face de suas tarefas" (MERLEAU-PONTY, 2011, p. 145). É a confirmação de uma estrutura vital que nada deve ao cogito como ato instituinte, mas que, sendo o momento da dialogia entre consciência e meio, estabelece uma correspondência global entre os meus gestos e os de outrem. Sendo assim, o corpo não é nem objeto (em-si) nem ideia (para-si) no meio (mundo), mas vivência: experiência de um corpo-próprio (sujeito) em relação com o âmbito das situações que lhe excedem e lhe amparam. Mundano, o corpo-próprio é, portanto, intersubjetivo - intercorpo!

Engajado nas coisas e veículo daquilo que sou no mundo, o corpo-próprio é o pivô a partir do qual sou presença e me faço presente: "é o termo não percebido para o qual todos os objetos voltam sua face" (MERLEAU-PONTY, 2011, p. 122). Furtivo ao tratamento que as ciências desejam lhe impor, ele não existe "como uma coisa inerte, mas esboça [...] o movimento da existência" (MERLEAU-PONTY, 2011, p. 125). Seus atos são a manifestação originária de um poder que, antes de qualquer posicionamento voluntário, nos impele a agir e modificar o meio, sabendo que aí há sempre um anteparo perceptivo. Trabalhando em vistas de um nada ativo que não repousa em si, a existência corpórea nos impele a viver os pactos individuais e coletivos que fomentamos com os outros. Por conseguinte, nada impede que eu me ausente de minha "existência pessoal, 
mas é apenas para reencontrar em meu corpo a mesma potência [...] pela qual estou condenado ao ser" (MERLEAU-PONTY, 2011, p. 228).

Em Merleau-Ponty, do ponto de vista existencial, consciência e corpo estão em comunhão com o meio. Para além da ação autoconstitutiva do pensamento, não há aí polarizações ou relações hierárquicas, mas reciprocidade e codependência. Enquanto estrutura ambígua da existência, o corpo não está além ou aquém de mim; ele é "um percipiente-percebido que [...] inere no espaço e no tempo" (GILES, 1979, p. 238). Portanto, nem subjetivo nem objetivo, o corpo é uma entidade fenomênica que, sendo experiência para mim, sou eu vivendo as coisas que habito.

Paradoxal, o corpo sente seu próprio estranhamento quando tenta tocar-se tocando. Como veículo do enraizamento mundano, ele é um objeto que ao mesmo tempo sou eu presente em meu campo perceptivo. Longe de quaisquer determinações dualistas, é um corpo-sujeito cujas intenções o levam a agir como uma totalidade portadora de todas as correlações possíveis. Assim, como síntese implícita e misteriosa de nossa existência, viver um corpo é, num só tempo, ser e perceber-se.

Para Merleau-Ponty, esta ambivalência "não é uma imperfeição da consciência ou da existência, é sua definição" (MERLEAU-PONTY, 2011, p. 445). Ser corpo, então, é viver a experiência originária pela qual não estou diante de um objeto; sou este objeto, pois sou meu corpo, inalienável e inevitávelmente. Evidenciando, com isto, o âmbito de codependências entre essência e existência, o autor diz que as funções humanas estão pressupostas em relações de codependências. Sensível entre sensíveis, a corporeidade exprime "a potência de se juntar às coisas e se sincronizar com elas" (DUPOND, 2010, p. 13). Ela é a gênese que dá sentido e lugar às nossas experiências. Por conseguinte, enquanto princípio que, encarnado, percebe, se move, deseja e sofre, é ao mesmo tempo princípio motor, lugar da expressão e ser sexuado. E se é pelo corpo que o ser vai ao mundo, é pela afetividade que vemo-nos coabitados por outrem. Revisitemos, pois, as dimensões da sexualidade e ve- 
jamos como Merleau-Ponty abre-nos aos outros, revelando o nosso estilo de ser ao acentuar a permanente dialética entre existência e afetividade.

\subsection{As dimensões da sexualidade e a promiscuidade com a existência.}

De acordo com Merleau-Ponty, a relação que mantemos com outrem está incluída na relação do corpo consigo. Contudo, não há como pensar a corporeidade sem ter em conta sua implicação n'outras realidades sensíveis. Para além de uma experiência para mim, é preciso considerar uma atmosfera que, intersubjetiva, confirma nossa mundivivênica, mas não se apresenta como independente da infraestrutura existencial. Enquanto fato que só tem sentido para nós, é preciso vislumbrar o modo como os outros se apresentam pelos afetos, desejos e paixões para, só assim, compreender como existimos e somos. Não objetivas, nossas relações com outrem se constituem "através do nosso ser total, em que o caráter afetivo se faz presente desde o início" (FURLAN, 1998, p. 242). E se a meta da fenomenologia é descrever como as coisas se apresentam sem radicalismos, é na afetividade onde Merleau-Ponty encontra um ponto de apoio à diferenciação.

Para o francês, as lentes deterministas do empirismo e do intelectualismo se afastam dos estados elementares de nossas vivências quando concebem a sexualidade como um modo de representação causal da consciência. Do ponto de vista epistêmico, o foco em processos extrospectivos ou introspectivos acarreta o condicionamento e a perda de certas representações, bem como "um enfraquecimento do prazer" (MERLEAU-PONTY, 2011, p. 214). Em detrimento destas correntes puristas e absolutistas, Merleau-Ponty entende que, se corpórea e intencional, a afetividade não pertence nem à reflexologia condicionada nem ao entendimento puro, mas liga-nos ao mundo e aos outros, involuntária e cegamente. Disto, mostra-nos que, entre o automatismo e a representação, existe uma zona vital e espontânea onde se elaboram as possibilidades motoras, perceptivas, intelectuais e eróticas de cada qual. 
Segundo esta perspectiva, é preciso que consideremos uma atmosfera implícita, segura e subjacente aos atos voluntários. Trata-se de encontrar na existência um Eros e uma Libido capazes de animar um mundo original, dar significação sexual aos estímulos e esboçar, "para cada sujeito, o uso que fará de seu corpo" (MERLEAU-PONTY, 2011, p. 215). Projetada entre as coisas, a sexualidade vem acentuar o modo como, vivendo um corpo, encontro-me nos outros. Intencional e codependente, trata-se de um corpo onde a afetividade é a "maneira de existir com ou contra os outros, de viver neles ou por eles" (CHAUI, 2002, p. 68).

Em inalienável relação com estes outros que, como eu, são seres carnais e afetivos, é na sexualidade onde encontro o prolongamento de minhas intenções. De fato, o corpo de outrem e o meu são, dissemos, "o verso e o reverso de um único fenômeno" (MERLEAU-PONTY, 2011, p. 470). O contato com a alteridade através da diferenciação expressa o modo pelo qual fazemo-nos signos neste mundo intercorpóreo. Não plenamente voluntária, a sexualidade traz à baila um saber sedimentado que não é pura experiência para mim ou para o outro. Pela afetividade, sou para outrem e outrem é para mim! Juntos, somos esta confusão, da qual ninguem se destaca. Carnal, o erotismo não é um cogito que busca uma falta cogitada. Assim, se sou meu corpo, viso invariavelmente outro corpo; e a sexualidade "se faz no mundo e não em uma consciência" laborativa (MERLEAU-PONTY, 2011, p. 217).

Para Merleau-Ponty, impera, na sexualidade, uma compreensão prévia do mundo que não faz parte da consciência tética, mas que, desejante, liga-me aos outros. Trata-se de "uma intencionalidade que segue o movimento geral da existência e que se abranda com ela" (GILES, 1979, p. 257). Relacional, a afetividade é a chave da dialética entre o em-si e o para-si! É o locus da mutua pressuposição entre realidades contraditórias porém indissociáveis: "é a tensão de uma existência em direção a uma outra existência que a nega e sem a qual [...] não se sustenta" (MERLEAU-PONTY, 2011, 231). Portanto, como horizonte de abertura, o corpo sexuado projeta e situa nosso 
estilo de ser em relação ao tempo e aos outros. Ao escopo desta análise, isto faculta-nos o resgate de uma dimensão existencial da vida afetiva, agora compreendida segundo a mútua pressuposição entre existência e erotismo.

Com efeito, em Merleau-Ponty a sexualidade ampara a forma geral da existência, pela qual projetamo-nos no mundo e construímos nossa história. Da compreensão de que o homem é um devir em relação às demais realidades sensíveis, o autor sustenta uma abordagem existencial da afetividade. A sexualidade deixa, pois, de constituir um ciclo independente. Presente desde o início, ela está ligada ao nosso ser por inteiro, mediante relações de trocas e reciprocidades. Sendo assim, enquanto signo privilegiado do nosso estilo de ser, observa-se uma intimidade entre vida afetiva e existência. Dialogia esta que nos faz repensar não só as teorias clássicas, mas a experiência erótica segundo a teoria psicanalítica.

Com efeito, considerando os limites desta análise, não aprofundaremos as contribuições de Merleau-Ponty sobre a psicanálise. Visto que Judith Butler refere-se predominantemente ao modo como fenomenologia e existencialismo são aplicáveis ao conjunto das teorias feministas e de gênero, não nos interessa comentar as distintas facetas suscitáveis nas interlocuções entre Freud e Merleau-Ponty. Não obstante, ainda que o autor da Fenomenologia da Percepção (1945) transvalore do arcabouço freudiano, ocorre que suas considerações são notórias e fundamentais à compreensão de sua teoria. Neste sentido, é preciso reconhecer que, se existe comunhão entre fenomenologia e psicanálise, tal diálogo parte do seguinte entendimento: o humano não é o resultado de processos absolutamente fisiológicos ou intelectivos. Vital à compreensão daquilo que conceituaremos como ato performativo, isto indica que tanto a fenomenologia quanto a psicanálise constatam que o humano, sendo esta libra de carne no mundo, também é um constructo histórico-social.

O enigma freudiano, diz Merleau-Ponty, reside em encontrar "na sexualidade as relações e as atitudes que anteriormente passavam por relações e atitudes de consciência" 
(MERLEAU-PONTY, 2011, p. 218). Por mais que seu arcabouço conceitual seja objetivista, é fato que os signos psicanalíticos buscam desvelar nas funções corpóreas uma dialética capaz de reintegrar os impulsos eróticos no homem. Diante disto, não há como alegar que Freud contradiz o método fenomenológico! Ele contribui ao sustentar "que todo ato humano 'tem um sentido', e procurar [...] compreender o acontecimento, em lugar de relacioná-lo às condições mecânicas" (MERLEAU-PONTY, 2011, pp. 218-219). Para além de atividades instintuais e genitais, pulsão e libido expressam - via sonhos, atos falhos, símbolos substitutivos, imagens egóicas, jogos de palavras, etc. - o poder que "o sujeito psicofísico tem de aderir a diferentes ambientes, de fixar-se por diferentes experiências, de adquirir estruturas de conduta" (MERLEAU-PONTY, 2011, p. 219). E é, pois, na sexualidade onde encontramos a chave daquilo somos com os outros.

Posto que a meta da pulsão é a satisfação em objetos reais ou fantasiosos, para a teoria psicanalítica, surgem problemas quando o indivíduo fixa suas ações n'algum dos estágios pré-genitais (anaclítico, oral ou anal) e, incapaz de seguir o fluxo normal do erotismo, experimenta em sua conduta efeitos que, visíveis para o outro e involuntários para si, são vividos no corpo, mas não pertencem à consciência. Em função de um ordenamento social que visa manter sob controle as paixões, é interessante, então, que esta força seja orientada pelo terapeuta de modo tal que, de uma tese formulada pelo consulente em "terceira pessoa", o mesmo não só traga à consciência seus desejos, mas aprenda a lidar com eles de modo objetivo, sabendo sempre o que aí subjaz. Contudo, se é a sexualidade quem tece nossa história pessoal, eis aí um problema. Se a sexualidade está pressuposta na existência, jamais deve ser postulada como uma realidade autônoma. Desde a primeira pessoa do singular, a afetividade está ligada à nós por inteiro. Assim, é preciso indagar se complexos descritos por Freud "exigem de fato um sistema de noções causais através do qual ele os interpreta, e que transforma as descobertas da psicanálise numa teoria metafísica da existência" (MERLEAU-PONTY, 2006, p. 276). 
Para Merleau-Ponty, uma explicação causal de nossa conduta resulta apenas numa teoria segundo a qual o conjunto das ações humanas só é compreensível a partir de certos quadros patológicos. O arcabouço freudiano não é, pois, "um quadro da existência humana, mas um quadro de anomalias" (MERLEAU-PONTY, 2006, p. 279). Formuladas em "terceira pessoa", suas explicações são anedóticas. Dirigem-se aos atos pessoas, mas dão conta apenas dos aspectos mensuráveis dos nossos afetos e paixões. Por conseguinte, por mais próxima que seja da fenomenologia, há algo de censurável na metapsicologia! Influenciado pelos pressupostos cientificistas de sua época, Freud só consegue indagar, por exemplo, a histeria se parte de uma tese objetivista formulada na terceira pessoa do singular e, assim, a trata como "efeito de um conflito intrapsíquico intolerável que, não obstante ter sido tornado inconsciente, continua produzindo manifestações" (MULLER-GRANZOTTO, 2005, p. 401)

Isto estabelecido, se, para a psicanálise, curar-se é reviver e liquidar de forma inteligível os nossos conflitos, em Merleau-Ponty, já que os afetos estão imbricados na corporeidade, eles se conectam com a atividade do coito, mas aí não se limitam, pois a transbordam. Ainda que mais tarde revise alguns destes posicionamentos, Merleau-Ponty entende que Freud transforma a sexualidade num impulso a priori, determinante da ação humana. Se grande parte de suas anedotas envolvem a afetividade, isto é "porque a atitude geral do ser no mundo [...] sempre envolve a sexualidade [...] como um momento expressivo da relação entre corpo próprio e mundo" (FERRAZ, 2006, p. 101). Portanto, se para Freud a libido é estritamente sexual, para Merleau-Ponty ela pode estar ligada aos processos de diferenciação, mas não se limita ao sexo em sentido estrito, pois é apenas um dos modos de ser corpo neste mundo inter-humano.

Não se trata, pois, de saber se a existência humana advém da sexualidade, mas de questionar o que se entende por sexualidade! Em psicanálise, vigora um duplo entendimento: "por um lado, ela insiste na infra-estrutura sexual da vida; por outro, ela 'incha' a noção de sexualidade a ponto de integrar a ela toda a existência" (MERLEAU-PONTY, 2011, pp. 219-221). 
Mas como a afetividade não pode ser circunscrita num só entendimento, não há sentido "dizer que a existência se compreende pela vida sexual" (MERLEAU-PONTY, 2011, pp. 219-221). Ao fim das contas, faz-se primordial que, via sexualidade, retomemos a existência como o meio de comunicação entre os corpos.

Imbricada na existência, a sexualidade funde os nossos posicionamentos com os de outrem. Vivendo-a em nosso corpo, nossos atos podem ser pessoais sem passarem pelo crivo tético da consciência e fisiológicos sem constituírem parte de uma causalidade de estímulos extrínsecos. Fundamental à constituição do sujeito, a sexualidade é não apenas um signo privilegiado da existência, mas a oportunidade de familiarizarmo-nos com a humanidade em seu drama primordial. Corporificados, os afetos asseguram que somos autônomos e dependentes uns dos outros.

Sem ser objeto expresso da consciência, a vida afetiva fomenta a forma geral da existência humana. Através dela, projetamo-nos no mundo e adquirimos um estilo de ser em relação aos outros. Mundana, a sexualidade é uma atmosfera polivalente, coextensiva à vida. Ela se encarrega de uma dialética global que encontra na ambiguidade o anteparo originário de nossa existência. Assim, se não é possível rastrear na sexualidade o polo determinante de nossa conduta, é pelo fato dela estar arraigada na existência que um indivíduo só tem história pessoal se possui história sexual. Existência e sexualidade se difundem mutuamente!

Isto posto, Merleau-Ponty sustenta que, seja qual for a direção, a cada instante brota de nós uma intenção que nos projeta no mundo e impele a viver em situação. Ora, se tudo o que vivemos tem múltiplos sentidos, então a sexualidade é a presentificação de um campo de indeterminação que, por sua conta e risco, sempre escapa à possibilidade de estereotiparmos uma ação como estritamente erótica. Visto que todo ato humano possui um sentido sincronicamente corpóreo, afetivo e existencial, a sexualidade representa um dos modos pelos quais estamos investidos no mundo. Neste sentido, se todo posicionamento voluntário é também a retomada de uma explicação sexual, então resta dizer que sexualidade e existência são osmó- 
ticas: "se a existência se difunde na sexualidade, a sexualidade se difunde na existência" (MERLEAU-PONTY, 2011, p. 234). Trata-se de reconhecer que vigora na existência humana um princípio de indeterminação que não apenas escapa às representações téticas da consciência, mas também não diz respeito à qualquer falha cognitiva.

Em função de sua estrutura, a existência é uma transcendência ambígua, indeterminada e misteriosa. Sendo o lugar de nossa abertura e comunicação com outrem, ela é a encarnação do movimento de retomada e transvaloração dos contextos factuais. Situacional, é uma transcendência incapaz de abandonar a sí, pois "nunca ultrapassa nada definitivamente" (MERLEAU-PONTY, 2011, p. 234). Em permanente tensão, ela não admite fatos puros, haja vista que é o "movimento pelo qual os fatos são assumidos" (MERLEAU-PONTY, 2011, pp. 234-235). Deste modo, se é verdade que a relação do homem consigo e com os outros está amparada por um subsolo de sentido não particularizável, não há engano quando assumimos, desde Merleau-Ponty, que todas as funções humanas são rigorosamente solidárias entre si. Inacabada em função de sua estrutura, não há na condição humana predicados absolutamente necessários ou contingentes. Diante da ambiguidade afetiva que nos constitui, tudo nos é necessário e contingente, pois constantemente refazemo-nos "na existência através dos acasos do corpo" (GILES, 1979, p. 260).

Na contramão das pretensas hierarquizações, Merleau-Ponty diz que a afetividade não é autônoma sobre as demais atmosferas da vida. Presente em nosso ser por inteiro, ela está "integrada ao conjunto do comportamento" (MERLEAU-PONTY, 2006, p. 234). Sendo assim, não se limita a um aspecto transcendente ao fenômeno da vida, centrada em representações inconscientes. Ao escopo de nossa análise, isto significa: além de uma espécie natural, o homem é uma ideia histórica. Nele não se configuram posses incondicionais ou atributos furtuitos. Não-necessários, tudo o que somos, o somos em relação ao outro: em relação a esta base de situações que fazemos nossa, que sem cessar transvaloramos, dramatizamos e performa- 
mos, mas que jamais é totalmente livre. Por conseguinte, não há explicação da sexualidade que não se reduza a ela mesma, pois, sendo o que é, já é algo além de si. A sexualidade é o nosso ser por inteiro. Nela, engajamos "toda a nossa vida pessoal" (MERLEAU-PONTY, 2011, p. 236).

Pressuposta desde a consciência perceptiva, a imbricação entre sexualidade e existência garante, segundo Merleau-Ponty, um afastamento das concepções essencialistas que enclausuram o humano num polo significativo. Para o autor, se é fato que, enquanto presentificação do nosso ser, o corpo também é a expressão geral de nossa existência, então não existe qualquer "ultrapassamento da sexualidade, assim como não há sexualidade fechada sobre si mesma" (MERLEAU-PONTY, 2011, p 236). Portanto, se há na sexualidade um horizonte de significações intencionais, ninguém está inteiramente salvo ou totalmente perdido. Sendo carne no mundo, todo ato humano sempre possui diversos sentidos. E como é de se esperar, as dimensões da sexualidade estão envolvidas em cada um deles, segundo relações de promiscuidade e codependência.

\section{Butler leitora de Merleau-Ponty}

\subsection{Para dar conta da diferença sexual.}

Ao fim da década de 1980, Judith Butler busca resgatar a relevância da fenomenologia sobre as teorias feministas e de gênero. Para ela, grande parte dos significantes feministas contemporâneos advém da máxima "ninguém nasce mulher: torna-se" (BEAUVOIR, 2009b, 361), cujos frutos são resultados da tradição existencialista e suas considerações sobre a corporeidade. Assinalando aí um emaranhado de possibilidades aptas a redimensionar os problemas de gênero, Butler reavalia os axiomas adotados pelas fenomenologias, no intuito de refletir sobre os matizes que, apesar de formulados, estão implícitos nestes discursos. Não exegéticas, tais leituras criticam a concepção existencialista de sujeito, sugerindo uma revisão às noções de corpo e mundaneidade. Reveladora, a leitura de Butler encontra nas obras de nomes como Sartre, Merleau-Ponty e Beauvoir 
o uso incipiente das categorias de gênero. Permeada por várias disciplinas, ela empenha-se em deslocar certas ferramentas do feminismo filosófico para dar lugar à teoria dos atos performativos. E é no limite das teorias fenomenológico-existenciais que, revisando-as, encontra amparo aos estudos sobre gênero.

Segundo sua interpretação, o método fenomenológico visa explicar como - através do corpo - os agentes sociais constituem linguística e cotidianamente o mundo social. Todavia, ainda que pressuponham uma capacidade interpretativa prévia ao uso voluntário da linguagem, muitos intérpretes tratam os agentes sociais não como sujeitos, mas como objetos dos atos constitutivos. Assim, quando afirmam que ninguém nasce mulher, não raro repetem os vícios da consciência objetal, passando por alto o fato de que o gênero não é nem uma identidade estável nem o lócus a partir do qual decorrem os atos pessoais. Balizado pelos vícios da diferenciação sexual, o existencialismo sustenta que, de forma tênue no tempo, o gênero é um constructo descontínuo capaz de instituir a identidade por meio da estilização de certos atos que, diante de outrem, se repetem de modo quase natural.

Na contramão de essencialismos e substancialismos, Butler entende que o gênero é uma construção performativa na qual a plateia e seus atores o creditam tal como a realidade. Para além de quaisquer dinâmicas imagéticas, a identidade de gênero é vivida na concretude histórica do corpo-próprio e de suas relações com outrem. Estilizada em função da repetição de certos atos no tempo, o gênero não é um constructo homogêneo! Não-estático, sempre existirá a possibilidade de transvalorá-lo. Desta feita, é em oposição aos modelos interpretativos que generificam o sujeito antes de sua lida cotidiana que Butler define os atos performativos não só como constitutivos da identidade, mas como objetos de crença - "a compelling illusion" (BUTLER, 1988, p. 520).

Atentando aos limites do existencialismo, a autora demonstra que as performances de gênero jamais deixam de ser atravessadas por sanções coletivas, mas é justamente por ser performáticas que podem transvalorar as condições que as rei- 
ficam. Trata-se, então, de tomar a fenomenologia como ponto de apoio para "fundamentar una concepción performativa de 'agencia' y, en un sentido amplio, de 'política"' (FEMENÍAS, 2003, p. 20). Isto posto, vejamos o que - em função dos atos performativos, da constituição do gênero e dos problemas feministas - Butler nos diz sobre a tradição fenomenológica. Disto, acentuemos as acusações e elogios que tece sobre a corporeidade e a sexualidade em Merleau-Ponty.

\subsection{Gênero e atos performativos: comentários sobre fenomenologia.}

Em Performative Acts and Gender Constitution: An Essay in Phenomenology and Feminist Theory (1988), Butler argumenta que as teorias feministas têm se mostrado reticentes quanto as teses que explicam as mulheres a partir das diferenças fisiológicas. Da distinção entre sexo e gênero, têm se considerado insuficiente tratar o sexo como o único fator determinante das vivências femininas. Dentre as teses críticas, as fenomenologias que versam sobre a corporeidade têm se mostrado interessadas nas distinções entre a anatomia e os significantes que o corpo assume em seus contextos situacionais. É em textos como O Ser e o Nada (1943), a Fenomenologia da Percepção (1945) e O Segundo Sexo (1949) que, em torno da liberdade, busca-se refletir sobre questão da sexualidade e, assim, assumir que o humano é uma ideia histórica, não uma espécie natural. De modo significativo, fala-se, ainda, das mulheres e, nos dias de hoje, dos gêneros não como simples fatos fisiológicos, mas como constructos indentitários sócio-culturais.

De fato, exceto n'O Ser e o $\mathrm{Nada}^{88}$, a facticidade do corpo não é negada, mas separada dos processos pelos quais as-

$88 \quad$ Balizado pela sintaxe de uma ontologia fenomenológica, Butler entende que Sartre reedita certos "fantasmas cartesianos" ao afirmar 1) que é pela ação nulificante da consciência que a unimos a certo objeto vivente no mundo e 2) que o corpo "ou bem é coisa entre coisas, ou bem é aquilo pelo qual as coisas a mim se revelam" (SARTRE, 2014, p. 386). De fato, se a percepção é constituinte dos atos reflexivos, então "sou meu corpo na medida em que sou" (SARTRE, 2014, p. 412). Contudo, segundo Sartre, também é preciso admitir que "não sou meu corpo na medida em que não sou o que 
sume seus significantes culturais. Feminino ou masculino, ser corpo é fenômeno ativo de apropriação e encarnação das possibilidades histórico, afetivas e intersubjetivas. Assim, se por acaso Beauvoir ${ }^{89}$ e Merleau-Ponty desejassem descrever o corpo generificado, ambos necessitariam de uma compreensão ampliada dos atos mundanos, de modo que fosse possível rastrear tanto aquilo que constitui os significantes incorporados em primeira pessoa, quanto o modo como tais signos são parodiados e transvalorados. Em síntese: os atos pelos quais os gêneros são constituídos tem vasta proximidade com a ideia de que, na verdade, estes atos são performativos, ou melhor, de que estes atos são personificados teatralmente, mas vividos no mundo humano. Diante disto, a tarefa de Butler reside em examinar de que maneiras os gêneros são constituídos por atos corporais e, neste sentido, quais as transfigurações civilizacionais permitem aventar (Cf. BUTLER, 1988, p. 521).

Por exemplo, quando Merleau-Ponty argue em favor da percepção e das vivências intersubjetivas, sustenta que o cor-

sou; pois dele escapo por minha nadificação" (SARTRE, 2014, p. 412). Ora, se o corpo é o ponto de partida para aquilo que sou, então só é necessário enquanto "obstáculo a ser transcendido para ser no mundo, ou seja, como obstáculo que sou para mim mesmo" (SARTRE, 2014, p. 412). Para nós, isso significa que, apesar de endosar a dialogia entre em-si e para-si, Sartre focaliza a identidade pessoal num ponto fixo quando, em razão da consciência como transcendência, transforma o corpo numa imanência intrínseca.

$89 \quad$ Sobre isto, devemos salientar que Butler se põe a tarefa de examinar os nuances implícitos no "tornar-se mulher" de Beauvoir. Deste mergulho, a estadunidense insinua que, mesmo sem dar-se conta, a autora d'O Segundo Sexo teria distinguido sexo e gênero, dando a entender que o gênero é um aspecto culturalmente adquirido da identidade (Cf. BUTLER, 1986, p. 35). Para Butler, o "tornar-se mulher" possibilita-nos compreender que, se existe algo natural, é o sexo; o gênero designa um agrupamento de apreciações instauradas históricamente. Ser "mulher" não é, então, um dado natural. Ser mulher é ter-se tornado mulher! Neste sentido, ser um gênero é tornar-se um gênero! Não obstante, enquanto verbo, tornar-se é dotado de um sentido ambíguo que, desde o marco existencialista, pressupõe conceitos como "eleição e "projeto". Segundo Butler, isto parece suscitar a incorporação de uma escolha voluntária. Mas se o gênero implica uma escolha, como pode ser um constructo social? Afinal, "nos construímos como mujeres o somos construídas como mujeres" (DÍAZ, 2008, p. 42)? Daqui, segue o antagonismo entre os posicionamentos voluntaristas e deterministas que perpassam o conjunto das obras butlerianas. 
po é não só um constructo histórico, mas um leque de possibilidades continuamente realizáveis que adquirem significado através de suas vivências concretas, historicamente mediadas no mundo (Cf. BUTLER, 1988, p. 521). Enquanto horizonte de oportunidades situacionais, sua aparição não pode ser determinada por quaisquer essências intra-psiquicas. Ser corpo é viver uma concretude intencional que, não meramente factual ou material, jamais será idêntica a si mesma. Teatralmente dramática, as vivências corpóreas assumem seus significados materializando, continua e incessantemente, suas possibilidades sociais e intersubjetivas.

Não obstante, alegar que a corporeidade é fruto de um "eu" desencarnado que o precede e o governa é assumir uma gramática desafortunada: "a unfortunate grammar" (BUTLER, 1988, p. 521). Com efeito, se corpóreo, o "eu" é uma maneira de materializar suas oportunidades. Intencional, a corporificação é a estilização das convenções e situações históricas feitas, dramatizadas e reproduzidas contextualmente. Construir o gênero, neste sentido, é não apenas um modo de vir à superfície, de ser e estar aberto à percepção de outrem, mas uma maneira de estilizar a existência: "'a stylistics of existence" (BUTLER, 1988, p. 521). Este modo de ser jamais se autoestiliza! Sua existência é imbuída de uma materialidade histórica que o condiciona e o limita, para além das facultações estritamente voluntárias. Feito em ato, o gênero é, pois, um modo de ser intencional e performático. É um constructo situacional, dramático e não referencial. Um estilo que, como indivíduos corpóreos, assumimos mundana e intercoporeamente, para além de decisões conscientes e voluntárias.

Isto posto, quando, em função dos axiomas adotados pelo existencialismo francês, Beauvoir diz que tornar-se mulher excede os dados naturais, para Butler aí jaz a distinção entre sexo, como fato anatômico, e gênero, como interpretação cultural dessa facticidade (Cf. BUTLER, 1988, p. 522). Segundo sua leitura, se, desde Beauvoir, "mulher" é um vocábulo destituído de significados imanentes, então ser mulher é induzir o corpo a se conformar com uma ideia histórica de "mulher". Materializar- 
-se mulher é ter se tornado mulher, obedecendo ou resignificando as situações que lhe são lançadas. Ser mulher é tornar-se um gênero, responsabilizando-se por suas consequências. Assim, se tornar-se um gênero é humanizar-se perante outrem, então não é possível que exista uma essência, um fato ou um objeto ideal que externalize o que os gêneros são. Não é um fato biológico quem configura o gênero, mas o modo como, em ato, esta ideia é socialmente parodiada, performada, sustentada e transvalorada. Construídas em ato, as performances de gênero ocultam sua gênese, pois partem de um consentimento coletivo tácito que o concebe, o sustenta e o credita tal como um fato natural. Por este motivo, por mais ficcional que seja, a constituição do gênero faz com que ela surja como natural e necessária.

Ora, mas em que medida a fenomenologia é funcional à descrição feminista dos gêneros? Para Butler, a fenomenologia contribui às teorias feministas quando funde teoria e práxis, revelando que o mundo é produto de atos decorrentes das vivências subjetivas. Ora, tal como na fenomenologia, muitas feministas compreendem não só que as estruturas sociais são implementadas por práticas individuais, mas que as situações pessoais são melhor analisadas sob a ótica dos contextos compartilhados. Boa parte destas teses pressupõe que os dramas individuais não são inteiramente particulares, mas dispostos socialmente. Condicionada pelo meio, a atmosfera pessoal é, pois, implicitamente política! Todavia, sustentar que o público e o privado são dialógicos não quer dizer que as situações particulares deixam de ser pessoais por serem vivenciadas por outrem. Significa apenas que os atos pessoais encarnam situações genefiricadas, e isto ocorre de distintas maneiras. Considerando que o pessoal é também político, que os gêneros são constituídos por atos mediados e, enfim, que o corpo só é cognoscível em sua forma generificada, então trata-se de sugerir que o corpo só se torna gênero por uma série de atos renovados, revisados, consolidados e historicamente sedimentados (Cf. BUTLER, 1988, p. 522-523).

As apropriações feministas das teses fenomenológicas facultam-nos entender que os atos que nos constituem são am- 
bíguos. Para Butler, isto significa: atuantes, as performances de gênero são expansivas ao ponto de incluírem, já na primeira pessoa do singular, estruturas mais amplas. Diante disto, reconhecemos que, vividas nos corpos, certas ações de gênero são ações instrumentais de organização e resistência coletiva que, sabendo ou não, favorecem relações sociais mais igualitárias. Não obstante, não há como passar por alto que, para favorecer laços de solidariedade, algumas destas apropriações supõem o gênero "mulher" como uma categoria universal e, em nome da libertação de quem é tratada como Outro ${ }^{90}$, fomentam a falsa promessa de uma eventual solidariedade política (Cf. BUTLER, 1988, p. 522-523).

De fato, inseridas na sociedade falocrata, as teses feministas apoiadas na fenomenologia têm o exito de, apesar da opressão, reconhecer a importância das mulheres sobre o conjunto dos saberes. Não há, segundo Butler, como negar tal contribuição! No entanto, é sintomático que, ao dar visibilidade às mulheres, tais apropriações pouco se empenham em examinar o estatuto das categorias que adotam e, assim, atentar às opressões cujos resultados levam à reprodução irrefletida de uma identidade de gênero construída segundo as categorias binárias da diferenciação. Ao declararem, por exemplo, que "mulher" é uma "situação histórica", as fenomenologias enfatizam que o corpo

90 Em suas obras, Beauvoir busca "descrever a condição da mulher" (BEAUVOIR, 2009a, p. 145). Indagando suas vivências, a autora nota que "em todo caso, o homem se colocava como o Sujeito e considerava a mulher como um objeto, o Outro" (BEAUVOIR, 2009a, pp. 145-146). Ora, se há uma forma humana positiva, esta é masculina; a mulher "aparece como o negativo" (BEAUVOIR, 2009b, p. 16). Destituída de significação própria, a mulher é o corpo; a encarnação daquilo que o "homem decide que seja" (BEAUVOIR, 2009b, p. 16). Ela é o sexo: o símbolo da diferenciação que só se determina em relação aos signos fálicos. Assim, enquanto o homem é pensado segundo sua autonomia, a mulher "é o inessencial" (BEAUVOIR, 2009b, p. 17). Se o "homem é o Sujeito, o Absoluto; ela é o Outro" (BEAUVOIR, 2009b, p. 17). Ela é o Segundo Sexo que, reduzido à condição de objeto de consumo e desejo, perde não só a condição de corpo fenomênico, mas é suprimida a "pura presencia ante el logos dominante masculino" (SÁENZ, 2009, p. 97). Para Beauvoir, nulificada em sua própria transcendência, a cultura exclui a mulher toda ação racional, autônoma e livre. No escopo das fenomenologias-existenciais, entendemos que tanto Beauvoir quanto Merleau-Ponty buscaram reagir contra este tipo de abordagem. 
sofre um processo de aculturação pelo qual assume um conjunto de convenções capazes de estruturar o modo como somos percebidos. Ora, interpela Butler, mas se o gênero é um signo cultural assumido por um corpo sexuado, torna-se impossível separá-lo da sexuação biológica. Diante disto, resta à fenomenologia assumir seus limites! Resta-lhe reconhecer que a encrustação do gênero no sexo resulta numa série de ficções imperativas, tais como o sexo natural ou a verdadeira mulher (Cf. BUTLER, 1988, p. 524). Além disto, outro efeito bastante questionável é a ereção de regras excludentes que, ao longo do tempo, produzem uma série de estilos corporais reificados pelos axiomas do binarismo de gênero e dos contratos heteronormativos.

Segundo Butler, boa parte das civilizações são regidas por regulações que, visando suas metas, dispõem a afetividade diante de tabus que visam somente assegurar o status quo e punir os transgressores. Uma das maneiras de perpetuar e ocultar esse sistema é cultivando os corpos em sexos distintos. Assim, no que tange a fenomenologia, trata-se de saber se ela contribui à reconstrução feminista do caráter sedimentado do sexo, do gênero e da sexualidade no nível corpóreo (Cf. BUTLER, 1988, p. 525). Com efeito, o interesse fenomenológico nos atos pelos quais a identidade é assumida pode servir de pivô às teses feministas que visam compreender como os corpos generificados são concebidos. O modo como, na primeira pessoa do singular, estes corpos dramatizam as vivências intersubjetivas possibilita-nos vislumbrar os distintos modos de atuação das convenções sociais. Todavia, é cada vez mais difícil imaginar a opressão sofrida pelas minorias tomando como ponto de partida apenas os atos individuais. Por mais que as responsabilidades coletivas preexistam, isso não implica que a opressão decorra apenas deles. Existem situações onde certos atos não só são avessos às convenções, mas capazes de transvalorar suas condições. E é neste sentido que a faceta performativa da subjetividade impõe uma revisão das premissas individualistas subjacentes ao enfoque fenomenológico.

Assim como na teoria feminista, o âmbito "pessoal" apresentado na fenomenologia se expande ao ponto de incluir 
as estruturas coletivas. Enquanto inscrição temporal de uma performance, os atos individuais são pessoais e coletivos. Na medida que dramatizam e resignificam o status quo, é então factível que os atos de gênero vividos no corpo assumam um enfoque teatral cuja orientação abranda tanto os voluntarismos exacerbados, quanto os determinismos absolutos.

Ora, é vestindo, parodiando e resignificando as normas, os axiomas e os contratos civilizacionais que, corporificados, os gêneros jamais podem ser confundidos com as ações de alguém isolado. Com efeito, não é que não existam configurações provenientes de escolhas individuais, mas o fato de muitas destas serem feitas em nome das sanções que pretendem negar mostra que, na verdade, o gênero não é só uma questão pessoal. Performáticos, os gêneros são pessoais, mas já estavam sendo realizados antes do sujeito entrar em cena. Tal como numa peça teatral, o gênero é um ato ensaiado que depende de seus atores para ser atualizado e reproduzido como realidade. Portanto, enquanto performance pública, não é nem individual, nem fruto daquilo que é culturalmente inscrito sobre ele. Feito em ato, o corpo generificado não só não depende de um "eu" prévio que lhe confere significâncias culturais, como não é um recipiente anorgânico passivamente roteirizado pelas regulações civilizacionais. Dentro da performance que parodia, o ator (corpo generificado) está desde sempre inscrito e situado no palco em que atua (mundo inter-humano). E assim como uma peça necessita tanto de um roteiro quanto de um intérprete, também o sujeito corporificado atua em seu papel (gênero) dentro de um espaço cultural prévio (Cf. BUTLER, 1988, p. 526)

Não obstante, é para além do contexto teatral que estas configurações se manifestam. Inscrito mundanamente, performar gênero é um ato de perigo e enfrentamento, pois aí não estão traçadas linhas rígidas que diferenciam ficção e vida. $\mathrm{Na}$ rua ou no ônibus, não há para uma trans qualquer presunção de que sua performance é contrastável com a realidade. Visto que não prestam contas às normas pré-existentes, as configurações de gênero estruturam uma nova realidade. Em devir, não se limitam à distinção "sexo-gênero", pois desafiam a separação 
entre realidade a aparência. Feitas em ato, tais paródias prescindem de cristalizações essencialistas. Sendo assim, enquanto for performada, a performance de uma trans é tão real quanto a de qualquer pessoa.

Reais em ato, os gêneros não são, portanto, expressivos, mas performáticos. Contra as fenomenologias, isso indica que os gêneros não são anteriores aos atos pelos quais são dramatizados e conhecidos. Nas várias maneiras onde a corporeidade assume e reconfigura seus significantes, não há qualquer egoidade prévia por meio da qual as ações pessoais e coletivas são mensuradas como verdadeiras ou falsas. Para além de ficções heteronormativas, alegar que a realidade de gênero é fruto de performances sociais indica, então, que os essencialismos adotados pelas teorias feministas apoiadas na diferença sexual também formam parte de uma estratégia hegemônica e excludente, segundo a qual o aspecto paródico dos gêneros é constantemente ocultado. Para Butler, contudo, o gênero é um ato em sentido amplo. Como performance, ele constrói uma paródia social de sua interioridade psíquica. Neste sentido, jamais será verdadeiro, falso, real, aparente ou ontologicamente necessário!

Com efeito, se é verdade que Butler não prescinde de uma teoria que defina os gêneros, então resta entender que, sem uma autocrítica, as teorias feministas, existenciais e fenomenológicas tampouco são capazes de avaliar como as opressões cotidianas fundamentam as categorias pelas quais os gêneros são concebidos. Ora, se é possível recomendar - como o Kristeva o fez" ${ }^{91}$ - que utilizemos o termo "mulheres" apenas como ferramenta política, é preciso, com isto, indagar quais vantagens de se colocar em cheque o estatuto metafísico desta categoria (Cf. BUTLER, 1988, p. 529). Uma coisa, é utilizá-lo sabendo de sua insuficiência ontológica; outra é articular uma visão de mundo normativa que o celebra como uma realidade cultural não atestável. Sendo assim, não interessa à estadunidense reescrever o gênero "mulher" de modo a torna-lo ontologicamente essencial às querelas políticas. Antes de mais nada,

$91 \quad$ Para Butler, Kristeva recomenda que as feministas se valham da categoria "mulheres" apenas como ferramenta política (Cf. BUTLER, 1988, 529); (Cf, BUTLER, 1989b). 
faz-se vital uma genealogia dos meios institucionais pelos quais os gêneros são configurados. Só assim entenderemos que, ao intitular-se fundador da cultura, o paradigma da diferença sexual passa por alto a possibilidade de uma avaliação de sua constituição, tanto pela via universalizante da tradição fálica, quanto pela perspectiva das teses feministas que constroem uma ficção metafísica, em nome da qual reivindicam a libertação de uma classe subjugada (Cf. BUTLER, 1988, pp. 529-530).

Amparados pelos pressupostos fenomenológicos, trata-se, enfim, de indagar uma genealogia crítica dos constructos de gênero que priorize uma concepção de ampla de ato que, além de performativo, é historicamente constituído e socialmente compartilhável. Tal genealogia, diz Butler, inclui uma política de atos performativos que não só redescrevem os gêneros existentes, como expõem, elucidam e transvaloram os atos e as estratégias de reificação que constituem e ocultam os gêneros conforme os vivenciamos. Não ontologicamente sistematizável, esta via interpretativa reconhece a importância de se representar as mulheres, mas defende que tal representação não pode distorcer a coletividade factual que a teoria deseja libertar (Cf. BUTLER, 1988, p. 530). Em verdade, em relação aos discursos que conferem centralidade aos símbolos fálicos, não como há deixar de admitir quão benéficas e emancipatórias são as teses feministas balizadas pela diferença sexual. Contudo, persiste um problema quando esta baliza prescreve uma restrição binária aos corpos ou - como em Merleau-Ponty - um panorama conceitual implicitamente heteronormativo que não raro serve à descrição viciada das identidades de gênero e da sexualidade.

Para Butler, é vital que a fenomenologia compreenda: apesar do caráter arraigado do patriarcado e, neste sentido, da diferença sexual ser utilizada como marco à emancipação feminina, não é possível desconsiderar que, enquanto inscrição corporal e cultural, o gênero é um fator pertinente. Para além de quaisquer determinismos ou voluntarismos absolutos, os gêneros não são nem passivamente inscritos no corpo nem delimitados pela anatomia, pela linguagem, pelos símbolos de poder ou pela soberba do patriarcado. Enquanto performances 
vívidas de um corpo, os gêneros são aquilo que, constante e invariavelmente, se supõe sob coerção, diária e incessantemente, com angústia e prazer (Cf. BUTLER, 1988, p. 531). Sendo assim, visto que personificam paródias de crítica e enfrentamento, são suficientes para apontarmos aos vícios das teses fenomenológicas, mais especificamente ao heternormativismo de Merleau-Ponty. Vejamos o que Judith Butler nos diz sobre o filósofo da percepção.

\subsection{A crítica feminista ao corpo sexuado}

Em Deshacer el Género (2006), seguindo alguns dos passos de Merleau-Ponty, ao falar sobre os homossexuais, Butler sugere que a sexualidade não é nem um atributo privado, nem uma série de inclinações pré-delimitadas. Enquanto estilo de ser no mundo, a afetividade nos direciona aos outros. Ela revela que, como corpos sexuados, somos esculpidos por nossas relações de apego, autonomia e dependência. Intrínseca, ela é, desde o início, nosso ser por inteiro. Assim, "no es esta o aquella dimensión de nuestra existencia, ni la llave, ni la base de nuestra existencia, sino más bien coextensiva con la existencia" (BUTLER, 2006, p. 57).

Mas qual a relação disto com os apontamentos feitos até aqui? Com efeito, apesar do hiato temporal, é em "Sexual Ideology and Phenomenological Description..." (1989) onde Butler explicita seu interesse pelos supostos merleau-pontianos acerca da percepção, da corporeidade e de suas contribuições ao âmbito das teses feministas, principalmente no que tange sua proximidade e seu abismo quanto ao tornar-se mulher. Sobre isto, observamos: em função das atualizações beauvoirianas, apesar de reconhecer a relevância de Merleau-Ponty, Butler não só não o segue acriticamente, como tece críticas aos modos como o francês delimita o corpo sexuado. Isso ocorre porque a preocupação de Butler com os corpos performativos é encorajada pela utilidade que as configurações de gênero possuem sobre as teses feministas, na medida em que outrora foram esboçadas por Beauvoir. 
Para a estadunidense, não há como contestar que o Segundo Sexo se utiliza das contribuições de Merleau-Ponty. O problema é que, ao falar da mulher como o Outro, Beauvoir reformula e amplia a subjetividade encarnada, direcionando-a aos debates feministas e ao problema da emancipação. Assim, ainda que mais tarde Merleau-Ponty trate do toque e da carnalidade $^{92}$, fica claro que o conjunto da sua obra não viabiliza este tipo de direcionamento. Com isto, salientamos que os escritos de Butler sobre Merleau-Ponty demonstram sua "crítica a Merleau Ponty, en parte a través de las tesis de Beauvoir" (DÍAZ, 2008, pp. 56-57).

Não obstante, é preciso dizer que esta leitura de Judith Butler possui diversos matizes! Ora, se é fato que Merleau-Ponty atenta às insuficiências da tradição determinista, Butler o elogia enquanto serve à refutação das teses naturalistas que regulamentam a vida sexual. Considerando que, para Merleau-Ponty, a sexualidade designa um movimento espontâneo do sujeito encarnado com o mundo, numa primeira visada, parece que, de fato, uma filosofia da percepção tem muito a contribuir às pautas igualitárias do feminismo. Para além da simples ati-

92 Acerca da ontologia da carne a da teoria do entrelaçamento empreendidas por Merleau-Ponty em seus escritos tardios, Butler entende que, quando dois corpos se tocam, ambos abrem "camino para una aprehensión sensible del mundo" (BUTLER, 2016, p. 9). Com efeito, antes de qualquer posicionamento voluntário, já estou em "con un terreno de alteridad que no es restrictivamente humano" (BUTLER, 2016, p. 9). Segundo Butler, isso significa que aquém da intercorporeidade e da intencionalidade fenomenológicas, é só por uma ontologia do sensível e, portanto, da carnalidade que torna-se possível descentrar o olhar objetificante, entendendo que a reversibilidade do toque não é propriedade de um sujeito autoconstitutivo, mas de uma rede de significantes inalienáveis. Não se trata "de lo que toco del otro, o de mí mismo, sino de la condición de posibilidad del tacto, una tactilidad que excede cualquier tacto dado y que no puede reducirse a una acción unilateral realizada por un sujeto" (BUTLER, 2016, p. 33). Assim, segundo esta dinâmica híbrida e reversiva de entrelaçamentos entre os corpos, se não podemos tocar sem ser tocados, Bluter entende que, antes qualquer assimilação acrítica do projeto fenomenológico, a meta de Merleau-Ponty n'O Visível e o Invisível (1964) é rastrear como se forma o sujeito a partir de um toque que não pertence a ninguém. Neste escopo, assim como a carnalidade, o conceito de tato vem, então, apontar à "condición de posibilidad de tocar y ser tocado, una condición que estructura de modo activo aquello que a la vez hace posible" (BUTLER, 2016, pp. 33-34). 
vidade genital, pensar a dependência entre existência e afetividade desde as situações concretas, de modo a reestabelecer os componentes histórico-afetivos da sexualidade, pode colaborar ao reconhecimento da diversidade sexual. Segundo Butler, a proposta de que o corpo sexuado é uma ideia histórica pode, sim, ser aproveitada à formulação das pautas feministas e de gênero suscitáveis, por exemplo, desde $O$ Segundo Sexo ( $C f$. BUTLER, 1989a, p. 85).

Não puramente biologicista, a corporeidade em Merleau-Ponty nos faz tomar consciência da importância em compreender "las diversas maneras de dar sentido al mundo, de re-configurar significaciones, hábitos y actitudes heredados y construídos" (SÁENZ, 2009, p. 97). Tal como nas teses feministas provenientes do existencialismo, o corpo é não só o veículo da apropriação dos signos mundanos, mas um mecanismo em transformação. Não se trata de um fato cristalino e estático, mas de um estilo de ser e existir que o sujeito - apoiado numa situação história que o excede - realiza e dramatiza segundo suas possibilidades (Cf. BUTLER, 1989a, p. 86). Mas por mais que Merleau-Ponty viabilize uma ampliação da sexualidade e, assim, contribua aos discursos sobre a diversidade, é preciso indagar se sua filosofia é capaz de operar uma real mudança nos pressupostos que regulamentam o heteronormativismo. Para Butler, ainda que indague o sentido histórico dos atos corpóreos, Merleau-Ponty oferece uma interpretação da sexualidade que pouco refuta as normas do patriarcado! Isto ocorre pois, além de adotar a heterossexualidade como pressuposto normativo, o francês caracteriza "la sexualidad masculina como mirada descorporalizada que enfoca a su objeto de deseo como cuerpo y solo crudo cuerpo" (DÍAZ, 2008, p. 57). De fato, interpela o biologicismo, mas acaba repetindo o vício de se compreender as relações culturais entre os sexos a partir de um referencial fálico, universal e masculino.

Segundo a análise de Butler, por mais que Merleau-Ponty enfatize a faceta autônoma e dependente dos sujeitos corpóreos, a estrutura da percepção é misógina, heteronormativa e continuadora da tradição segundo a qual a mulher, condenada 
ao invisível, é a presentificação do imaginário masculino. Independentemente de quais tenham sido as inovações propostas na fenomenologia do corpo sexuado, o sujeito que visa outrem é um sujeito masculino que não só projeta "sus deseos sobre el cuerpo femenino sino que considera eso que es su proyección como la estructura misma del cuerpo percibido" (DÍAZ, 2008, p. 58). O corpo que este indivíduo fálico percebe é um corpo passivo, visualmente objetificado e, por assim dizer, feminino. Não importando quais olhares são detidos sobre este corpo, ele é visto de tal modo que seus atributos provocam, invariavelmente, os gestos fálicos. Por conseguinte, mesmo quando Merleau-Ponty assume a reversibilidade das mãos, o toque está sempre "repleto de matices solipsistas que excluyen al otro e ignoran la diferencia sexual, de manera que se limita a describir lo visible, ahora duplicado" (SÁENZ, 2009, p. 103). Para Butler, "here the solipsistic circle of the masculine voyeur seems complete" (BUTLER, 1989a, p. 94).

De fato, em Merleau-Ponty a sexualidade é a expressão da existência. No conjunto de sua obra, ambas estão pressupostas, de modo a tornar o corpo "un lugar de apropiación y un mecanismo de transformación” (SÁENZ, 2009, p. 118). Contudo, neste mesmo contexto, o corpo feminino não raro performado pelas mulheres parece conter uma essência física que, balizada pela diferença sexual, é determinada não como sujeito, mas como objeto da percepção. Tal corpo parece conter uma "essência objetiva" que elicia o desejo masculino. Ele não possui uma existência aberta, mas uma essência fixa que não se confunde com seu sujeito. Neste sentido, o corpo genérico nomeado por Merleau-Ponty, "ese cuerpo que es existencia, tiene que ser masculino" (DÍAZ, 2008, p. 58). E se o corpo feminino não é seu próprio sujeito, então "la existencia no pertenece a la mujer" (DÍAZ, 2008, p. 48).

Ao primar pela percepção, a tentativa merleau-pontiana de manter um sujeito genérico enquanto são descritas as experiências intercorpóreas é infecunda! O sujeito universal de que sua fenomenologia fala não deixa de ser um sujeito culturalmente determinado: um corpo androcentrico. Assim, na 
medida que em Butler nos referimos aos corpos performáticos, não é viável que invoquemos uma estrutura universal mediante a qual os casos particulares são compreendidos. Se desejamos efetuar uma crítica ao corpo sexuado, devemos reconhecer que as indagações merleau-pontianas tendem a conferir legitimidade e universalidade à uma forma da sexualidade pré-esboçada pela cultura. E por mais que a fenomenologia busque proporcionar uma compreensão ampla da afetividade e, assim, interpelar a regulações normativas, o fato é que, muito provavelmente, tais expectativas são ilusórias, pois o que prevalece é a "sexualidad masculina, la cual se caracteriza por una mirada des-corporalizada que define su objeto como un simple cuerpo" (SÁENZ, 2009, p. 118).

De fato, em Merleau-Ponty a afetividade situa-nos. Ela nos torna copartícipes de uma comunidade mais ampla. Contudo, o mundo do qual o francês fala não transborda as relações culturais de dominação, onde o homem é o ser que deseja e assiste (o voyeur) e a mulher, o ser desejado e objetivado; onde "el sujeto normal vidente es el hombre y el "cuerpo visto es el de la mujer" (SAÉNZ, 2009, p. 118). Sexista, Merleau-Ponty sustenta que a dialética entre os sexos está suposta nas vivências intercorpóreas, mas o que faz é conferir ao corpo uma estrutura universal supostamente a-histórica que, em função de um vício heteronormativo, passa por alto o fato de ser motivada por regulações culturais.

O autor explica essa estrutura alegando que a sexualidade é um modo de familiarizarmo-nos com a humanidade segundo seus laços de autonomia e dependência. Mas ao descrever a corporeidade a partir de uma estrutura fálica e alegar que somos codependentes uns dos outros, apenas reimprime a dialética existencialista do "Eu" e do "Outro". Segundo Butler, esta é somente uma maneira de atualizar a dialética do "senhor" e do "escravo" (Cf. BUTLER, 1989a, pp. 95-96). Portanto, se as palavras de Merleau-Ponty forem devidamente analisadas, notamos que apenas reeditam a ideia segundo a qual posso, enquanto corpo, ser "reducido a objeto por la mirada de otra persona para quien yo no soy persona; también puedo convertirme en el amo y mirar yo a la otra personal" (DÍAZ, 2008, p. 59). 
Para Butler, é preciso admitir a similaridade entre a ideologia merleau-pontiana da afetividade e a dialética hegeliana. Sexualmente situado, o modus operandi da percepção muito se assemelha ao do desejo. Assim, "el sujeto que desea es equivalente al amo y el objeto deseado al esclavo" (DÍAZ, 2008, p. 59). Ora, se o "senhor" é um existente descorporisado, o escravo é a personificação daquilo que falta ao amo. O que resta ao escravo, então, é assumir-se como objeto de desejo: o corpo faltante ao senhor. Tal qual a condição feminina, lhe é imputada a condição de um ser sem desejo; um ser inessencial e secundário. Em função disto, salta aos olhos como não existem, nesta dialogia, quaisquer corpos desejantes.

Diante dos comentários remetidos por Butler, notamos: seja na percepção, intersubjetividade ou reversibilidade das mãos, vigora em Merleau-Ponty a aceitação de uma estrutura metafísica da corporeidade. Por mais que não seja possível rastear um leque explícito de sinonímias como "senhor = sujeito desejante = corpo masculino" e "escravo = objeto de desejo = corpo feminino", Merleau-Ponty reproduz a compreensão de que o corpo feminino é um existente fragmentado. Adotando em grande medida o suposto beauvoiriano segundo o qual a mulher - reduzida pelo homem à condição de Outro - se conforma às vivências inessenciais da corporificação, para Butler, a descrição merleau-pontiana da afetividade parte de uma dinâmica heteronormativa. Assim, Merleau-Ponty não só esvazia a experiência feminina de referências culturais específicas, como a converte em uma estrutura ontológica que, se n'algum momento puder ser contextualizada, só o será mediante o marco heteronormativo. Metafisicamente confusa, tal problematização da sexualidade em momento algum assinala ou reconhece as relações culturais de dominação e submissão existentes entre os sexos.

Ora, quanto ao valor que a teoria de Merleau-Ponty pode ter aos debates feministas, Butler acredita que o problema da carnalidade esboçado tardiamente pode servir à estruturação de uma ontologia que, em detrimento do privilégio da visão, dá ênfase ao toque. Segundo a estadunidense, trata-se aí de uma 
descrição do erotismo onde a carne enquanto atmosfera de partilha resiste às categorizações normativas e aos dualismos sujeito-objeto. Não obstante, considerando que a Fenomenologia da Percepção interpreta o embate entre "senhor" e "escravo" como uma dinâmica invariante da vida sexual, Butler questiona se Merleau-Ponty foi realmente capaz de afastar-se das teses onde predominam o voyeurismo e a objetificação do Outro. Para ela, o autor d'O Visível e o Invisível (1964) cai em confusão ao acreditar que sua teoria retoma a primordialidade da experiência vivida e, assim, olvida o fato de que sujeito e objeto - senhor e escravo - são constructos metafísicos que em quase nada divergem dos prejuízos ontológicos clássicos (Cf. BUTLER, 1989a, pp. 97-98). Deste modo, a constituição merleau-pontiana do sujeito é, no mínimo, problemática, pois "pretende representar no a un género sino a todo género" (DÍAZ, 2008, p. 61).

Em favor de uma descrição da corporeidade, Merleau-Ponty passa por alto a possibilidade dos gêneros figurarem como categorias constitutivas da identidade. Assim, se só há sujeito enquanto persistir um estereótipo fálico de transcendência, então Merleau-Ponty consagra este universal como um modelo destinado à constituição de qualquer humano. Como observa Butler, tal consagração traz consigo sérias limitações, pois desvaloriza não o gênero, mas as mulheres (Cf. BUTLER, 1989a, p. 98).

Isto posto, à recusa do gênero para elucidar a objetalidade fálica, soma-se o fato de que não é possível rastrear em Merleau-Ponty qualquer historicidade da sexualidade dos corpos. Com efeito, se são muitas as sexualidades e se seus contextos linguísticos também são diversificados, então este hiato da teoria merleau-pontiana só pode ser visto como uma falta grave. Para dar acesso à "coisa mesma", "es fundamental la referencia a la concreta sexualidad y al concreto cuerpo del que se pretende hablar" (DÍAZ, 2008, p. 61). Assim, por mais prolifera que seja, a leitura merleau-pontiana da sexualidade é bastante ingênua!

Privilegiando uma perspectiva universalista, Merleau-Ponty reduz a concretude da vida a uma abstração metafísica, 
na qual não estão incluídas as situações particulares dos sujeitos corpóreos, constituídos histórica, social e culturalmente. Neste sentido, se é possível uma apropriação feminista de suas teses, Butler deixa claro que será preciso avaliar em que medida estas contribuições legitimam e universalizam as estruturas hegemônicas de poder, bem como a opressão sexual daí decorrente. Para além daquilo que uma fenomenologia do corpo sexuado é capaz explicitar, trata-se, pois, de entender o corpo como veículo performativo de expressão e dramatização dos elementos histórico-existenciais constituídos em gênero, e a sexualidade como uma atmosfera de lutas culturais passíveis à transvaloração, à inovação e à mudança.

\section{Conclusão: para além do corpo sexuado, gêneros performativos.}

No intuito de sustentar que a construção da identidade ocorre dramática e paródicamente, Butler não apenas avalia os méritos e limites das teses fenomenológicas, mas insiste que, se desejamos conceber os gêneros como atos performativos de um corpo-próprio, é preciso deixar claro em que medida as proposições de nomes como Beauvoir e Merleau-Ponty são produtivas aos discursos feministas e à compreensão das configurações de gênero. Ora, se é verdade que "ninguém nasce mulher" (BEAUVOIR, 2009b, 361), então o gênero jamais expressará uma identidade estática e substancial. Para Butler, o gênero é um constructo esboçado mediante atos descontínuos e repetitivos, abertos à transformação. Contra quaisquer concepções que possam querer coisificá-lo ou cristaliza-lo, ele é o resultado de uma performance mundana e social: "a performative accomplishment" (BUTLER, 1988, p. 520). Neste sentido, contra as narutalizações e binarizações, trata-se de abrir mão de uma nova compreensão das condições de formação dos gêneros, onde não são as formas, e sim os atos quem constituem e produzem a crença de que o gênero de um corpo atuante no mundo (sujeito ator) pode ser real.

Ao escopo de nossa leitura, isto aponta à necessidade de uma revisão do modelo fenomenológico empreendido por Mer- 
leau-Ponty. De acordo com Butler, Merleau-Ponty supõe um Eu prévio, fundante de nossas condutas e ações. De fato, diz ela, não dá para passar por alto que, para além das cristalizações anatômicas, a concepção da mulher como uma situação histórica encontra amparo na ideia segundo a qual o corpo perceptivo é uma ideia histórica construída intersubjetivamente. Em verdade, em Merleau-Ponty o aspecto fático e material da corporeidade não são negados, mas diferenciados de sua inserção cultural. Em função disto, Butler entende que as teses fenomenológicas precisam ampliar a compreensão sobre os atos que descrevem não só os modos como os corpos carregam seus significados, mas como estes são representados, dramatizados e performados.

Para ela, a fenomenologia precisa entender que o corpo não é só matéria fática. Não somos apenas um corpo disposto entre outros. Mundano, "el cuerpo se hace" (DÍAZ, 2008, p. 64). Enquanto se materializam, os corpos dramatizam suas situações. Diante disto, supor um Eu "fálico", prévio e descorporizado cujas facultações exercem poder sobre a corporificação é valer-se de uma gramática desafortunada.

Assinalando esta infeliz adversidade, Butler propõe que consideremos o gênero não como um universal impositivo sobre os casos particulares, mas como um ato ao mesmo tempo intencional, performativo, dramático e não-referencial: " $a$ corporeal style" (BUTLER, 1988, p. 521). Com efeito, é preciso dizer que Butler não abandona os marcos fenomenológico e existencial, onde noções como "intencionalidade" e "projeto" são vitais à liberdade do sujeito corporificado. Sua revisão sustenta apenas que a performatividade talvez seja mais adequada à "crítica al recurso al yo previo a la acción" (DÍAZ, 2008, p. 64). Intencionais, os gêneros performativos indicam não só que não há uma essência prévia aos gêneros, mas que são os atos de gênero que os criam e ocultam, facultando-nos a ilusão de que são reais e naturais.

Diante disto, trata-se de questionar se as contribuições de Merleau-Ponty podem servir às teses feministas que interpelam o caráter natural dos gêneros, dos sexos e da sexualidade. Estendendo suas críticas às fenomenologias, Butler ques- 
tiona em que medida os feminismos interessados em analisar a constituição dos corpos generificados encontram amparo na preocupação segundo a qual os corpos agem em conformidade com as situações civilizacionais oferecidas. Para ela, as fenomenologias - dentre elas, a de Merleau-Ponty - não dão conta deste problema! Ao sustentar que as opressões são mantidas e reproduzidas por agentes pessoais conformados aos poderes hegemônicos, tais discursos tomam como ponto de partida os atos individuais, mas raramente consideram o conjunto dos condicionantes sociais favoráveis à opressão.

Sob a ótica butleriana, isto é um grave equívoco, pois não há como passar por alto as situações culturais condicionantes da ação voluntária. Demasiadamente individualista, o enfoque existencial revela-nos, então, seus limites, pois não reconhece que é da perspectiva da ação compartilhada que brotam boa parte dos questionamentos relativos às opressões cotidianas. Concordando com o lema feminista, se é verdade que as vivências pessoais são, também elas, políticas/coletivas/sociais e, neste sentido, que é possível ampliar os valores subjetivos ao plano cultural, então é preciso dizer, contra a fenomenologia, que os atos pelos quais os corpos generificados são estilizados não são solitários: "the act that gender is [...] clearly not one's act alone" (BUTLER, 1988, p. 525). Performados e vividos em ato, os gêneros são efetuados em função de suas matizações pessoais, mas é em relação às sansões coletivas que torna-se impossível reduzi-los ao meramente individual.

Nunca plenamente autônomos ou originais, os atos de um corpo generificado atuante no mundo são "una suerte de ritual repetitivo de significados socialmente establecidos" (DÍAZ, 2008, p. 66). Assim, o gênero não é nem um projeto individual, nem um constructo extrínseco imposto sobre o corpo. Considerando, tal qual Merleau-Ponty, que o corpo não é simplesmente passivo aos códigos culturais, para Butler, os atos de gênero são, além de intencionais, dramáticos e performativos.

Ao contexto desta análise, isto significa que as performances de gênero colocam em suspenso inclusive a distinção entre realidade e aparência. Diferentemente daquilo que Mer- 
leau-Ponty e as fenomenologias-existenciais sustentam, as configurações de gênero não expressam "ninguna esencia interior sino que ellas mismas son las que constituyen la identidad de género" (DÍAZ, 2008, p. 67). Portanto, dos veios abertos por Butler, se é verdade que não existe uma identidade autêntica, natural ou universal, consequentemente, tampouco existirá qualquer configuração de gênero mais real ou mais verdadeira que as outras. E isto porque, segundo Butler, noções como "sexo natural" e "gênero verdadeiro" são apenas criações culturais fictícias que, em favor de suas próprias causas, encobrem e oprimem a faceta crítica e performativa das identidades de gênero.

Na contramão de certos individualismos, não restam dúvidas, então, de que pôr em questão os modos como as performances de gênero são estruturadas é fundamental ao conjunto das teorias feministas. Politicamente falando, não há como negar que a lutas emancipatórias ver-se-iam beneficiadas se, em determinadas situações, fossem amparadas por certos universais capazes de unificar o discurso de uma classe oprimida - a categoria "mulheres", por exemplo. Todavia, estas ficções só são úteis enquanto instrumentos políticos de luta, resistência e enfrentamento. Assim, se desejarmos empregá-las, que jamais as utilizemos como categorias ontológicas aptas a promover a real liberdade das minorias. Tratando-as como fantasiosas, Butler entende: para além das fenomenologias, não é que, em favor de certas causas, não possamos dispor destas categorias; a questão é que não podemos deixar de problematizá-las.

Assumindo, um importante direcionamento às teorias feministas e de gênero, Butler interpela a costumeira ênfase que se confere à celebração e à articulação normativo-prescritiva de uma essência, de uma natureza ou mesmo de uma cultura própria para as mulheres. Indagando se de fato existem "as mulheres" ou, ainda, se é possível falar desde um ponto de vista específico delas (Cf. BUTLER, 1988, p. 529), contra Merleau-Ponty e a fenomenologias, Butler diz que uma coisa é valer-se de uma categoria sabendo de suas insuficiências; outra é articular uma visão normativa que celebre e emancipe uma realidade inalcançável. Dispondo a diferenciação como pedra 
angular àquilo que deseja julgar e oprimir, as fenomenologias atenuam a investigação sobre o modo como se estrutura, organiza e dissemina a opressão sexual. Seja por um ponto de vista masculino e universalista, seja pela adoção da categoria "mulheres" como fator das proclamações feministas, Butler entende que, assim como o heteronormativismo compulsório, o pressuposto da diferença sexual, além de problemático, não é suficiente para dar conta da faceta crítica e performática em que estão inseridos os corpos generificados.

Diante disto, trata-se não só de pôr em cheque as filosofias que universalizam as categorias fálicas, mas de dar espaço e tornar presentes os constructos de gênero socialmente marginalizados. Para além da matriz binária, só assim compreenderemos que, ativas, as performances de gênero não estão fixadas nem pelo corpo, nem pela natureza, e tampouco pela simbologia fálica. Dramáticos, os gêneros dão lugar à uma ótica de reconhecimento pela qual as identidades alternativas assumem um papel crítico e reativo em relação às normas, regulações e sanções impostas dogmaticamente pela cultura masculina. 


\section{Referências:}

BEAUVOIR, S. A Força das Coisas. Rio de Janeiro: Nova Fronteira, 2009a.

, O Segundo Sexo. Rio de Janeiro: Nova Fronteira, 2009b.

BUTLER, J. Deshacer El Género. Barcelona: Paidós, 2006

. El género en disputa: El feminismo y la subversión de la identidad. Barcelona: Paidós, 2007

. Los Sentidos Del Sujeto. Barcelona: Herder Editorial, 2016

. Performative Acts and Gender Constitution: An Essay in Phenomenology and Feminist Theory. Theatre Journal [Maryland], v. 40, n. 4, pp. 519-531, 1988.

. Problemas de Gênero: Feminismo e Subversão da Identidade. Rio de Janeiro: Civilização Brasileira, 2003

. Sex and Gender In Simone de Beauvoir's Second Sex. Yale

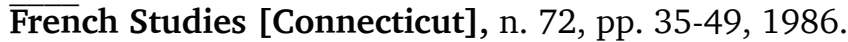

. Sexual ldeology and Phenomenological Description. A Feminist Critique of Merleau-Ponty's Phenomenology of Perception. In: ALLEN, J.; YOUN, I. M. The Thinking Muse: Feminism and Modern French Philosophy. Indiana: Indiana University Press, 1989a, pp. $85-100$

. The Body Politics of Julia Kristeva. Hypatia, Vol. 3, No. 3, pp. $\overline{104-118, ~ 1989 b . ~}$

. Variations on Sex and Gender: Beauvoir, Wittig, Foucault. In: BENHABIB, S.; CORNELL, D. (org.) Feminism as Critique: On the Politics of Gender. Minneapolis: University of Minnesota Press, 1987, pp. 128-142.

CHAUI, M. S. Experiência do pensamento: ensaios sobre a obra de Merleau-Ponty. São Paulo: Martins Fontes, 2002.

DÍAZ, E. B. Qué Cuenta Como Una vida: La pregunta por la libertad en Judith Butler. Madrid: A. Machado Libros, 2008

DUPOND, P. Vocabulário de Merleau-Ponty. São Paulo: Martins Fontes, 2010.

FERRAZ, M. S. A. O transcendental e o existente em Merleau-Ponty. São Paulo: Associação Editorial Humanitas, 2006.

FEMENÍAS, M. L. Judith Butler: Introdución a su Lectura. Buenos Aires: Catálogo, 2003.

FURLAN, R. Introdução à Filosofia de Merleau-Ponty: contrapontos com Freud e Wittgenstein. 1998. Tese (Doutorado em Filosofia) - Instituto de Filosofia e Ciências Humanas, Universidade Estadual de Campinas, Campinas, 1998. Disponivel em: <http://www.biblio- 
tecadigital.unicamp.br/document $/$ ?view $=$ vtls000129490 $>$. Acesso em: 03/02/2016

GILES, T. Critica fenomenologica da psicologia experimental em merleau-ponty. Petropolis: Vozes, 1979.

MERLEAU-PONTY, Maurice. A estrutura do comportamento. São Paulo: Martins Fontes, 2006. 2011.

Fenomenologia da percepção. São Paulo: Martins Fontes,

. O visível e o invisível. São Paulo: Perspectiva, 2012.

MULLER-GRANZOTTO, M. J. Merleau-Ponty leitor de Freud. Natureza Humana, São Paulo , v. 7, n. 2, p. 399-432, dez. 2005.

SÁENZ, M. C. L. Contribuciones De Merleau-Ponty A La Filosofía Feminista. Phainomenon, v.1 n. 18-19, pp. 95-124, 2009.

SARTRE, J. P. O Ser e o Nada: Ensaio de Ontologia Fenomenológica. Petrópolis: Ed. Vozes, 2014.

WAELHENS, A. Uma Filosofia da Ambiguidade. In: MERLEAU-PONTY, Maurice. A estrutura do comportamento. São Paulo: Martins Fontes, 2006. pp. I-XXV. 